\title{
The Working Poor Facing the Great Recession in Southern Europe
}

\author{
By Estelle Sommeiller
}

\begin{abstract}
The standard measure of poverty at work in Europe is the in-work at-risk-of poverty rate published by Eurostat. According to this indicator, the working poor in Southern Europe have somehow been affected by the financial crisis of 2008 and the Eurozone debt crisis that followed in 2010. Spain, Italy and Portugal display rates ranging between 9\% and 10\% in 2007 compared to $11 \%$ - 13\% in 2017. In Greece, in-work poverty declined from $14 \%$ in 2007 to $11 \%$ ten years later. Such a result may be surprising in the context of the austerity policy measures that marked the decade in this area of Europe. Using EU-SILC 2005-2018 microdata, this article aims to extend Eurostat's rates of in-work atrisk-of poverty in several ways. First, poverty lines are computed so as to be anchored in time: each of the four national poverty thresholds is set at 2008. Second, the statistical population of workers is expanded to include the people displaying weak ties to the labour market but still in the exercise of remunerated activities at some point of the year. Third, the black box of the household approach is opened thanks to Ponthieux's concept of poverty in earned income. Fourth, the poverty headcount ratios are supplemented by the two other measures that Sen suggested to adopt on a regular basis: the poverty gap (the economic distance separating the income of the poor from the poverty line) and the Gini index measuring how unequal the income distribution of the poor may be. Once those technical details are fixed, the question of working poverty is addressed over time (before and after the Great Recession) under its three fundamental dimensions: the labour-market, the family net, and the state institutions. (JEL J30, I30, E24)
\end{abstract}

Keywords: Measurement, Poverty in Earned Income, Standard Employment, Solo Self-Employment, Part-Time Work, Family Net, Labour-Markets Reforms.

\section{Introduction}

The core topic of this paper lays the emphasis on the links between poverty and employment. It aims at providing complementary measures of monetary poverty for people located at the bottom end of the labour market. Though a masterpiece of the international standards, Eurostat's indicator of in-work at-riskof-poverty may yield misleading results if solely used or not properly understood. Eurostat does provide many other indicators measuring poverty among the employees, the employed persons except employees, the not-employed persons, the unemployed or the retired. However, these indicators would be ideal in a virtual world where all other things are held constant. The occurrence of the 2007 -

\footnotetext{
"Researcher (chargée de mission), IRES, France.
} 
2008 financial crisis has changed the deal and comparing poverty at work before or after its onset requires some adjustments. This is one of the reasons why this empirical study is applied to the European countries that have experienced long years of economic recession, political and social turmoil in the aftermath of the debt crisis of 2010: Italy, Spain, Portugal and Greece. More than a geographical area bordering the Mediterranean Sea, Southern European countries share some cultural values, linguistic features, historical heritage, socio-economic development, and, among other things, strong subnational inequalities (Lombardy and Piedmont in Italy, the Basque region and Catalonia in Spain, northern Portugal, Athens in Greece). These economies also share the characteristics of a residual model of welfare state, in contrast with Northern European countries.

The first section explains the reasons why Eurostat's poverty standard measures need to be adjusted and complemented. The next three sections explain the choice of the variables finally selected at three levels: poverty thresholds, the definition of worker and the household dimension of the poverty indicator. An additional section is developed to specify more precisely which indicator is best suited to each dimension of poverty (low wages or lack of work, family and state). The last five sections finally get into the results, displaying the time trends of the alternative poverty measures: a) the share of poor people in standard employment and the extent to which the earned income of this subgroup falls short of the poverty line; the share of poor people in non-standard forms of employment ('solo' self-employment, and involuntary part-time employment) given the labour income they earn in a year; b) the share of people being poor in earned income and who living in a non-poor household; and within this group, the share of female workers; c) the individualised measure of poverty in labour income is left out at this point to consider the equivalised disposable income instead; income inequality among the working poor is measured by two Gini coefficients, one before and one after public social transfers.

\section{In-Work Poverty Rates: Measurement Matters}

The standard ratio counting the number of working poor in Europe is the socalled in-work at-risk-of-poverty rate published by Eurostat. In the total workingage population (18-64 years), Eurostat's in-work at-risk-of-poverty rates record the proportion of employees or self-employed working full-time or part-time over half of the year (preceding the SILC interview) and who live in a household whose disposable income per unit of consumption ${ }^{1}$ does not exceed the poverty line, which is set at $60 \%$ of the national median income. According to this indicator (see Figure 1), the shares of the working poor have somehow increased in Southern Europe throughout the last decade, except in Greece where in-work poverty dropped to pre-crisis levels. The in-work at-risk-of-poverty rates of the

\footnotetext{
${ }^{1}$ Consumption units have been designed to consider the economies of scale that individuals benefit from sharing the same dwelling place. An adult living alone represents 1 consumption unit; a couple 1.5; any other adult member aged 14 and over represents 0.5 , and a child under $14,0.3$.
} 
four countries all display a rather high degree of volatility, revealing no visible correlation to the curves of the economic cycle typical of that period of time.

Figure 1. In-Work at-Risk-of-Poverty Rates, 2005-2018

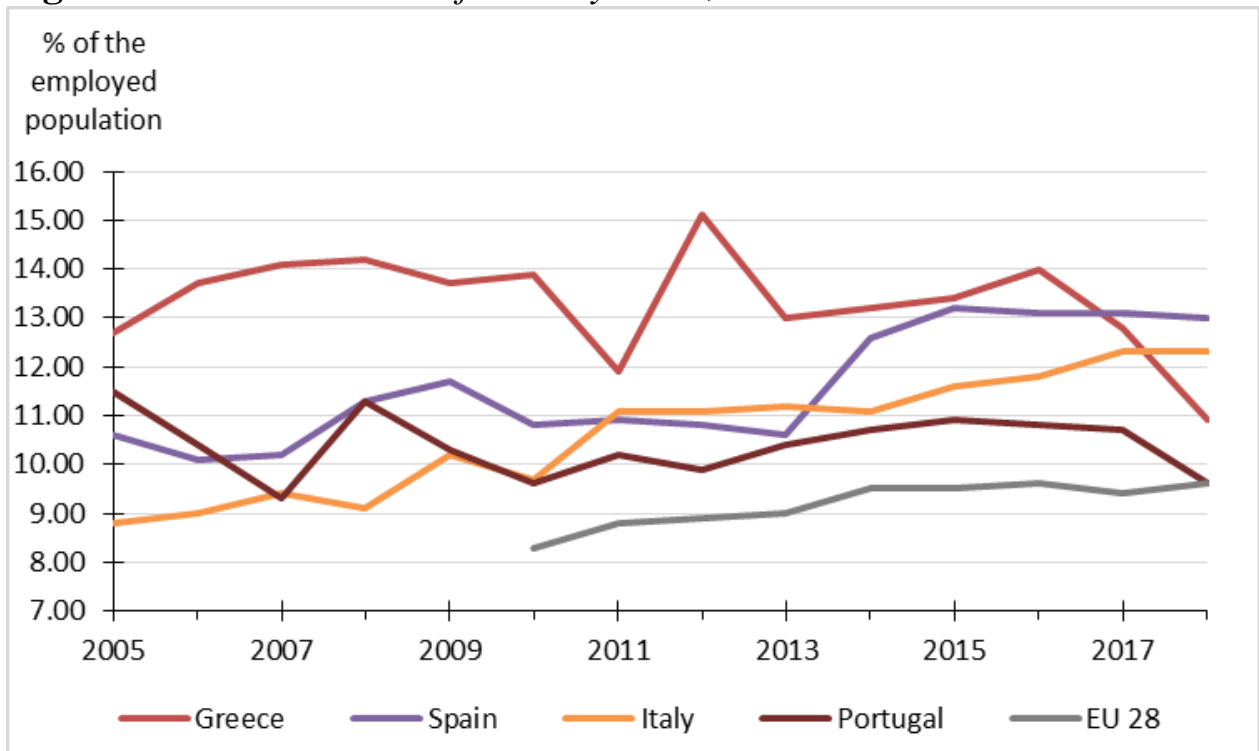

Source: Eurostat [ilc_iw01].

Note: Population of the 18-64 years-old persons being employed ("in-work"). The standard income threshold is expressed in current prices. The income measure is the equivalised disposable income expressed in current prices.

Looking at this graph may be puzzling to the untrained eye. Why is the time trend of working poverty so erratic in Southern Europe? One would have expected a sharp increase of working poverty for reasons that Eurofound $(2017$, p.15) state quite clearly: "Given the mechanisms that drive in-work poverty - including low wages and low work intensity - one would expect to have found it increasing during the crisis. An economic downturn could depress wages and decrease the number of hours employers pay for work, both of which would increase in-work poverty. Rises in unemployment would also adversely influence in-work poverty by decreasing the number of earners in a household. Furthermore, austerity measures could lead to the reduction of social transfers, further decreasing household income (Crettaz, 2015)". Before breaking it down, a closer look at how Eurostat's indicator is constructed may change the overall picture. There are three dimensions of Eurostat's definition of in-work at-risk-of poverty rate that require attention: the poverty threshold, the economic status of being employed, and its final computation at the household-level. Thanks to microdata from Eurostat EUSILC [footnote] it is possible to reconstruct alternative measures of poverty". [footnote] = "European Union Statistics on Income and Living Conditions (EUSILC), user database 2004-2017, version of 2019-03. European Union Statistics on Income and Living Conditions (EU-SILC), user database 2005-2018, version of 2019-09. Eurostat is not responsible for the methods and results of the project. The responsibility for all conclusions drawn from the data lies entirely with the author. 


\section{Poverty Thresholds}

With a poverty threshold based on a share of the median (or mean) income at the national level, the Eurostat indicators of poverty are not sensitive to any surplus of economic growth that would be equally shared across people. Had everyone earned a thousand times the income received a year earlier, in-work poverty rates would remain the same. Conversely in the case of an income loss. Differently put, the European measure of income poverty does not allow to determine whether a change in the poverty rate is due to a change in the national income or a change in the number of poor people. This is an issue when the national economies collapsed in Southern Europe in the aftermath of the debt crisis of 2010: Whenever the standard measure of income poverty goes down substantially, it is not possible to conclude that the number of poor people declined. It may also be the case that the national income fell faster than the average income of the poor. In Greece more than anywhere else, the European measures of poverty fail to capture the impoverishment of the population that other statistics such as the gross domestic product per capita suggest. How best to calculate a poverty line is an extensively debated question in the academic literature.

How much is enough to live on? What is an adequate minimum living standard? Which income level makes an adult person poor or non-poor? Answering these sensitive questions necessarily implies to make normative choices. The academic literature opposes the European view of a 'relative' measure of poverty, which essentially yields poverty rates that may be seen as income inequality indicators, to an Anglo-Saxon concept of poverty as an 'absolute' measure of the basics needs. Several alternative solutions were suggested. One of them includes non-monetary poverty indicators such as the material deprivation rate that has been included in Eurostat's 'Europe 2020 indicators'. It is defined as the percentage of population with an enforced lack of basic material necessities and consumer durables. Eurostat set out a list of nine material deprivation items in the 'economic strain and durables' dimension. A lack in at least three of them makes a person materially deprived. The material deprivation rate is not a poverty threshold per se, but an alternative measure to the standard poverty rate. Even though the material deprivation rate is "more absolute in nature" as Crettaz (2015) pointed it out, the poverty threshold used in the material deprivation rate remains the same as in the monetary poverty rate: $60 \%$ of the national median equivalised disposable income, leaving the problem unsolved.

Developed by Orshansky (1965) the same year that President Johnson declared war on poverty, the concept of poverty in the US refers to a minimum subsistence level for families of different size and composition. Orshansky's definition of poverty line gave birth to the so-called "poverty guidelines" used nowadays by the statistical authorities to determine whether a family is eligible to social assistance programs or not. If "it is not possible to state unequivocally "how much is enough," she writes, "it should be possible to assert with confidence how much, on an average, is too little". The US poverty line was therefore based on the average cost that a representative American household spent on the minimum food diet in 
1963. This cost simply was multiplied by three to yield the 1963 poverty line. Setting the multiplicative parameter at three comes from a statistical survey conducted by the Ministry of Agriculture in 1955 where the food budget of a typical American household represents one-third of its disposable income (after social transfers). The poverty line of the following years is adjusted for inflation according to the consumer price index. Hence the consistency of its time trend in real terms. By construction, the US poverty line necessarily lies below the other Western countries' poverty lines based on the national median (or mean) income.

In Europe since the early 1990s, the minimum income concept has echoed through the so-called "reference budgets" (Concialdi, 2014). Debating on how best to define a minimum income scheme in Europe, the European institutions recommended the member states to agree on a common method for drawing up such reference budgets (ONPES Report 2014-2015). In some countries like France and the UK, the reference budgets comprehend more than the survival income without which it is not possible to physically exist, with the concept of an individual's free choice to participate in the society's life (Crédoc, IRES, 2014). Such a comprehensive approach complies with the guidelines provided by the 2004 European Council: Due to income resources considered insufficient in the society in which they live, the poor "may experience multiple disadvantages through unemployment, low income, poor housing, inadequate health care and barriers to lifelong learning, culture, sport and recreation. They are often excluded and marginalised from participating in activities (economic, social and cultural) that are the norm for other people and their access to fundamental rights may be restricted". The standards of living that are derived from this comprehensive approach of reference budgets match quite closely the standards of living extracted from the national accounts macrodata. By nature, they both lie well above the income measures coming from household surveys like EU-SILC. In 2011, the average standard of living indicator from SILC surveys represents about $70 \%$ of the average standard of living indicator from the national accounts in Italy, and around 60\% in Greece, Spain and Portugal (Concialdi, 2014, p. 30 Figure 3). Consequently, reference budgets cannot be substituted to the conventional poverty threshold estimates derived from household surveys (they are not intended to do so). This conclusion is all the more robust because another methodological issue arises: At the lower tail of the income distribution, the OECD-modified equivalence scale used in household surveys underestimates the equivalised disposable income in comparison with the reference budgets of the same household type. For a couple with two children, the discrepancy between the two measures ranges from $10 \%$ to 15\% according to the 2014 study by Crédoc and IRES on the French reference budgets. By nature, reference budgets are not poverty lines. An absolute measure of poverty line is an international standard of exclusion. A reference budget is an international standard of inclusion. Therefore, the poverty lines, when derived from reference budgets and household surveys, refer to conceptual frameworks that are too far apart to substitute one to the other without producing misleading results.

Another way of defining the poverty threshold consists in anchoring its value at a fixed point in time, in real income terms (i.e. adjusted for inflation) as in 
Jenkins et al. (2013), Dicharry B., Terra I. (2016). Figure 2 compares two different threshold types over the past decade: the annual poverty thresholds in current prices (proper to the standard measure of in-work at-risk-of poverty rates) and the national thresholds of 2008 yearly adjusted for inflation thereafter.

By construction, the thresholds anchored in time follow a perfectly linear path in contrast with the volatile dashed lines of the $60 \%$ share of the national median income. In the remaining course of the paper, the poverty threshold adopted is Eurostat's at-risk-of-poverty threshold for a single-person household in 2008. It is adjusted for overall price inflation between 2008 and 2018 (annualised each year of the sample according to the average annual growth rate of the 2008-2018 time span). Cross-country comparison is now feasible in this regard. Eurostat does provide an at-risk-of-poverty rate with a poverty threshold anchored in 2008. It is not available by the employment characteristics of the working-age population like the standard in-work poverty risk is.

There is a time limit in the exercise of anchoring poverty lines in time. It might make sense over the very long run in the case of a poverty line defined as basic human survival needs, like the US one. However, in the European case where the poverty threshold is a share of the national income, it cannot be relevant for more than one economic crisis at a time. The double crisis of 2008 and 2010 is one. Beyond that point, it does not make sense any longer.

The question of which year to anchor poverty at results from an arbitrary choice that is arguable. It could be any year between 2005 and 2009 although it cannot be strictly precise because of the definition of the income reference period in SILC. Set at twelve consecutive months, the income reference period may be a moving period (such as the year preceding the date of the interview) rather than a fixed period of time (such as a tax year). The minor cross-country comparability issues it raises are here left unanswered ${ }^{2}$.

The median income considered for each country is a unique number per year, set at the national level for the whole population. It is not an array of median incomes estimated per family type as we sometimes encounter in the social sciences literature.

\footnotetext{
${ }^{2}$ For instance, in Ireland the Central Statistics Office (2018, p. 7) clearly explains the problem: "SILC is an annual survey. Information is collected continuously throughout the year with household interviews being conducted on a weekly basis. The income reference period for SILC is the twelve months immediately prior to date of interview. Therefore, the income reference period differs from household to household (depending on the interview date) and overall within the 2017 dataset we have income data spanning from January 2016 to December 2017. The CSO plans to change the income reference period from the 2020 SILC to the calendar year immediately preceding the SILC year. This means that the income reference period for the 2020 SILC will be from January 2019 to December 2019.”
} 
Figure 2. Poverty Thresholds Anchored at 2008 versus Standard Thresholds in Current Prices (Dashed Lines), 2005-2018

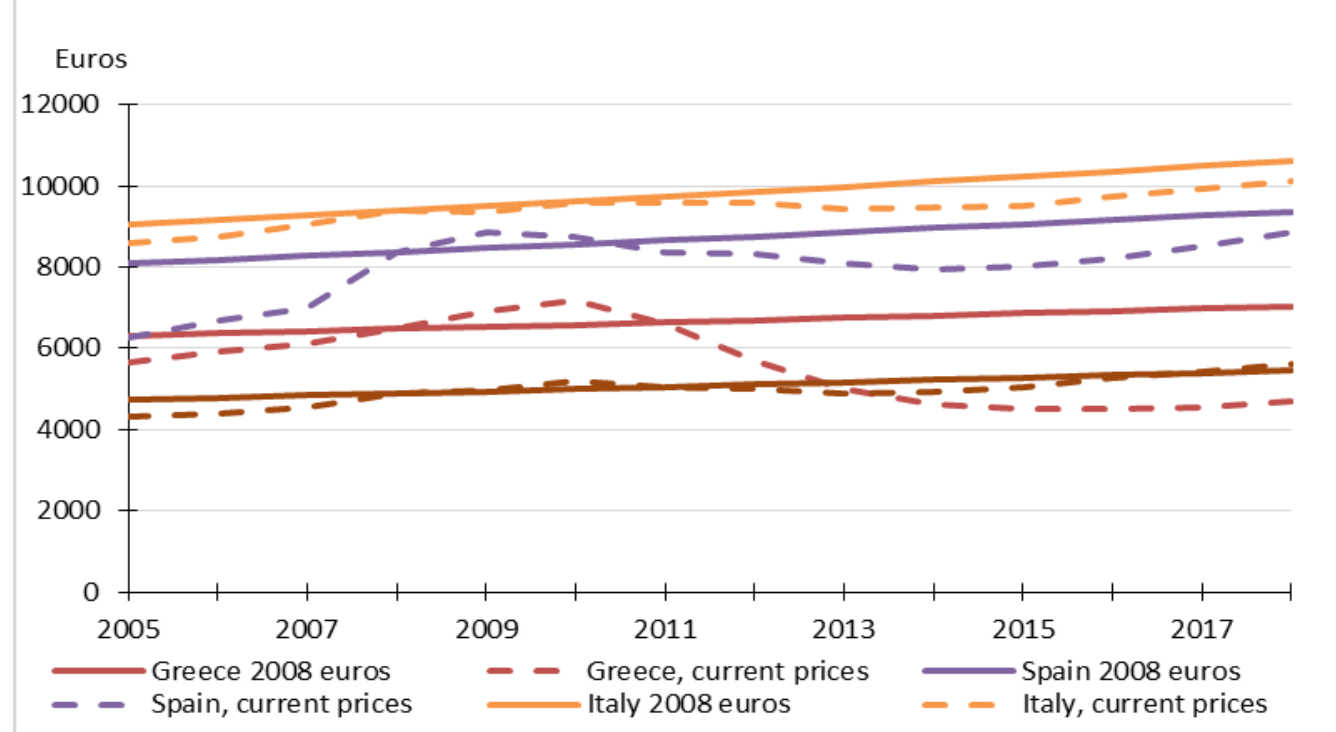

Source: Eurostat [ilc_li01] for the poverty threshold of a single-person household and Eurostat [prc_hicp_aind] for the harmonized index of consumer prices (HICP).

Note: The annual rates of change of the HICP provided by Eurostat are used to calculate one single overall growth rate over the 2008-2018 time period. The corresponding average annual increase is then applied to annualize the national poverty threshold of 2008 each year of the 2004-2018 time period. Hence the straight lines on the graph.

The second methodological question that the standard poverty risk indicator raises is the definition of being employed or 'in-work'.

\section{How Best to Count Workers?}

The in-work at-risk-of poverty rate applies to the population being employed. According to Eurostat, an adult person is said to be 'in work' or 'employed' whenever s.he has been working (full-time or part-time as employees or selfemployed) for at least seven months during the year preceding the interview. This definition accords with the definition of other groups of the working-age population, all based on the most-frequent activity status as the main criterion of definition. For instance, an adult person is considered unemployed whenever the cumulated number of months spent in unemployment strictly exceeds half a year. These population breakdowns look quite logical.

However, what it means to be a worker does impact the final poverty measure. Ponthieux (2010), Marx and Nolan (2012), Crettaz (2015), Horemans et al. (2016), and Horemans and Marx (2017) all pointed it out: the Eurostat definition of workers is restrictive. The ILO definition of worker entails at least one hour of paid work during the reference week. Theoretically, it includes all specific groups of working people, especially those displaying weak ties to the labour market. Precisely to include this population subgroup, Crettaz (2015, p. 135) proposes to adopt the ILO definition of work: "any person who held a job at the time of the 
interview is a 'worker', whatever her or his previous work record." However, applying the ILO concept to survey data may not be as straightforward as it looks: any person interviewed in between two temporary positions cannot be recorded at work as soon as the employment gap lasts more than a week, leaving those persons out of the sample. It is therefore possible that the sample of ILO-defined workers is not larger than the 'in-work' sample, if not smaller. It turns out to be the case in all of the EU-SILC annual releases. Arguing for a broader understanding of 'being in-work', Horemans et al. (2016, p. 7) use another variable of EU-SILC: the self-defined current economic status. "Because we do not want to exclude workers with weak labour market attachments, we consider people to be 'working' if they indicate that this was their main activity status at the time of the interview." The latter two definitions (working at least one hour during the previous week and selfdeclared current economic status) capture the activity status taken at one point in time, as of the time of the interview. They both miss the cumulative effect embedded in the concept of annual earnings. One variable does not: the number of months spent at paid work over the calendar year. The present contribution therefore considers a worker any person working at least one month a year, whether at a full-time or a part-time work, as an employee or a self-employed, in the working-age population (18-64 years-old). The number of months spent at work results from reliable cross-sectional variables (displaying almost no missing values) over all the EU-SILC annual editions.

Figure 3 displays the reconstructed poverty rates based on poverty thresholds anchored at year 2008 within the population of people whose equivalised disposable income includes at least one month of labour income in a year. Is the Great Recession appearing clearly on the graph this time?

Figure 3. Working Poverty, 2005-2018

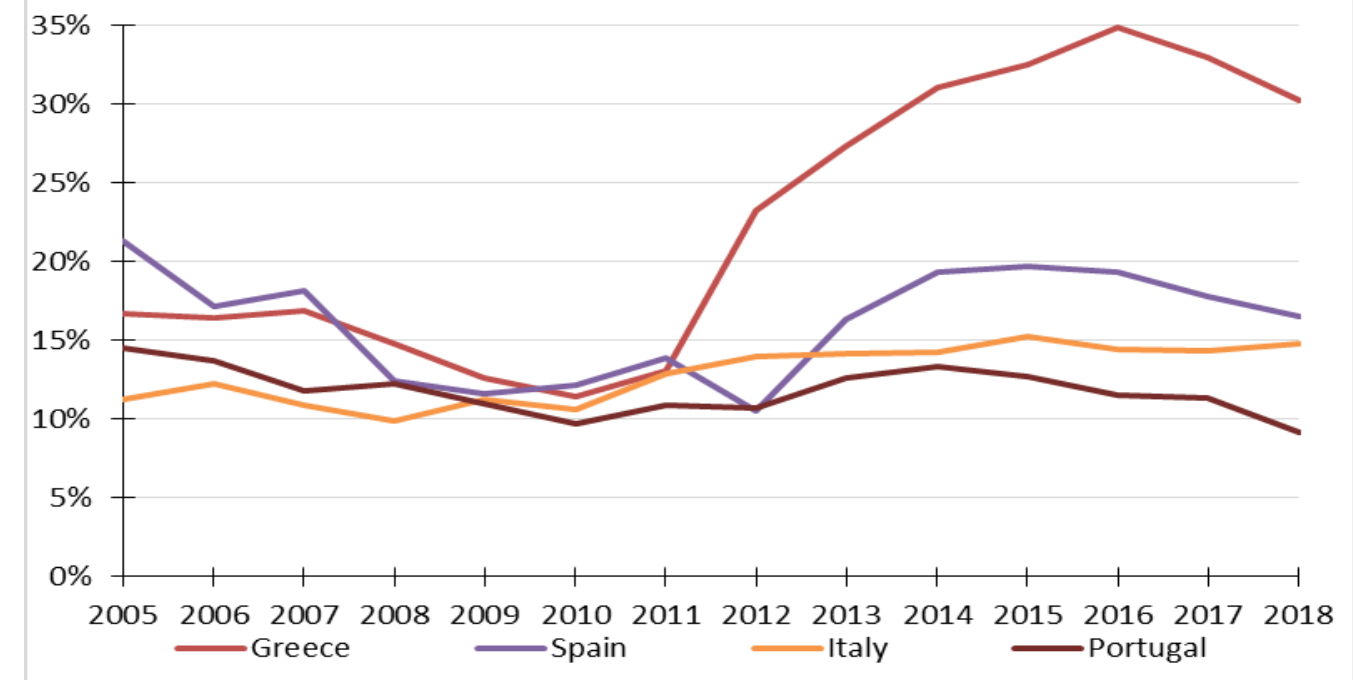

Source: Author's Own Calculations using EU-SILC Microdata.

Note: Population of the 18-64 years-old persons spending at least one month a year at work. Poverty thresholds anchored at year 2008 and adjusted for price inflation. The measure of income is equivalised disposable income expressed in current prices. 
Visually speaking, Figures 1 and 3 contrast in scale. The four countries record working poverty rates above $10 \%$ over the entire time-period, except in Portugal in 2018. Part of this result is necessarily explained by the overall growth rate of the poverty threshold $(8,8 \%, 11,8 \%, 13,2 \%$ and $11,5 \%$ in Greece, Spain, Italy, Portugal respectively) between 2008 and 2018. However, the explanatory factors at play cannot be reduced to the linear time trend of the poverty thresholds. The magnitude of poverty in Greece and Spain now appears clearly in the aftermath of the doublecrisis of 2008 and 2010 . The four national poverty rates converged to the $10 \%$ $12 \%$ interval in 2010 , the turning point of the time-period, before reaching a maximum level in 2016 for Greece, 2015 for Spain and Italy, 2014 for Portugal. The maximum point of $35 \%$ in Greece in 2016 speaks volume on the monetary turmoil that large shares of the working-age population have been going through for several years in a row. According to Figure 3, none of the four countries of Southern Europe, in terms of working poverty, has in 2018 recovered from the occurrence of the Great Recession, except Portugal.

That being set says nothing about the links between employment and poverty. The primary goal of the present contribution is to document the close association between the occurrence of the double 2008-2010 crisis and the chances, on a twotier labour market particularly segmented in Southern Europe, of the insiders and the outsiders of falling into poverty. With regard to the labour-market structure, further clarification is needed at two levels: the population of workers and the income sources. The population of workers mixes together working-age adults spending one month at work and others spending a full year at work. Combining months of employment with months of unemployment or inactivity blurs the frontiers between working poverty accruing to low-paid job (wage effect) or working poverty accruing to insufficient amount of work (employment effect). Within the population of workers, the subgroup of 'standard' workers, i.e. the employees working full-time in an open-ended position (permanent contract) is distinguished from the group of adult persons working in atypical forms of employment. The latter group itself is further divided into two subgroups well known for being highly exposed to the risk of poverty: the self-employed hiring no staff and the part-timers who wish to work more hours but who cannot for economic reasons. Shedding light on the wage effect separately from the employment effect also requires to focus on earned income sources at the personal level rather than equivalised disposable income at the household level. Opening the black box of the household's total income is the purpose of the next section.

\section{Separating the Individual Dimension from the Household Dimension of Poverty}

Whenever poverty is analysed from a labour market perspective, a statistical mismatch occurs between an equivalised measure of income and personal labour earnings. By definition, equivalised income adds together the various income sources from all adult members of the household and then divides this total by the household equivalised size, so as to take into account the economies of scale 
realized in a housing unit dwelling more than one single adult. In other words, any person working in a low-paid job is not considered at risk of poverty whenever $\mathrm{s}$-he lives in a household with equivalised income above the poverty line. Defining in-work poverty this way leads to the gender paradox: Men are statistically recorded as poorer than women under the poverty approach whereas more women than men are poor from a low-paid employment perspective. The gender paradox holds true in all of the four Southern European countries over all years using the standard measure of equivalised disposable income. To avoid any bias in the results, the gender literature suggests individualised measures of income. Meulders and O'Dorchai (2010) provide a fully-individualised measure of income, i.e. all income sources are expressed per capita. The two authors derive from it a series of poverty indicators specific to numerous family configurations in nine countries of the European Union using the 2006 edition of EU-SILC. Their approach does capture the personal dimension of poverty. Ponthieux (2010) suggests an alternative measure, poverty in earned income, where the sources of income all relate to the state of being, or having been, in work (wages, self-employed income, sickness and unemployment benefits). Poverty in earned income means poverty of individuals 'as if' they were living on their own and only off their personal earnings. Her poverty line is the traditional Eurostat at-risk-of-poverty threshold. She then compares two ratios: the share of workers being at risk of poverty (as defined by the standard indicator) and who are also poor in earned income, as well as the share of the same in-work poor who are not poor in earned income. Adding a gender divide to her estimates, she succeeds in assessing two of the social forces impacting working poverty, low earnings and large families, in the European Union member states based on EU-SILC of 2007. In the economic literature, Allègre (2012) breaks down the equivalised disposable income into three main pieces, each representing the three major institutions impacting in-work poverty: labour market, family, and state. He reconstructs poverty indicators from individual wage income to equivalised disposable income. He derives conclusions on the standards of living inequalities of six European countries in 2007. . Mussard and Pi Alperin (2011) decompose the poverty growth by income source components (and by population subgroups) in order to avoid the underestimation of poverty growth in Scandinavian countries in 2006 and 2007.

The final choice in this paper is directly inspired from Ponthieux's concept of poverty in earned income in that the income measure we resort to is the labour income at the personal level. Individual earned income includes individual wage earnings and replacement wages. Individual wage earnings sum altogether employee cash or near-cash income, non-cash employee income, cash benefits or losses from self-employment. Replacement wages mean unemployment benefits, old-age benefits, sickness benefits and disability benefits. Only the net series of SILC income components are considered, i.e. the income net of social contributions and taxes on income ${ }^{3}$. Using labour-income at person-level, the gender paradox

\footnotetext{
${ }^{3}$ As Ponthieux (2010) pointed it out, this may be an issue for the income measure at the personlevel. The observed net income includes a possible impact of the household composition, especially on taxes. The proper adjustments to perform would require a complex micro-simulation model such
} 
over-representing male poverty is solved in all of the four Southern European countries over all years of the sample.

To the best of our knowledge, there is no academic articles using EU-SILC microdata to compute individualised measures of poverty across countries and annually over long periods of time.

\section{Income Measures Suited to the Main Dimensions of Poverty}

In the labour-market section, the goal pursued is twofold. First, it is set at sorting out the part of working poverty accruing to low-paid employment from the part of working poverty due to insufficient amount of paid work. Second, it goes beyond the proportion of people living below the poverty line by considering the income shortfalls of the working poor, known as the poverty gap. This concept developed by Sen (1976) reveals the intensity of poverty by measuring how far the income of the poor deviates from the poverty line.

In the family-related section, the goal is to appreciate the income evolution of a specific group: the share of people being poor in individual labour income but living in a non-poor household (the numerator is the headcount ratio of poverty in individual earned income; the denominator counts all households whose equivalised disposable income lies above the poverty line; both poverty thresholds are anchored in time (2008) and the statistical population include the working-age individuals spending one month a year or more in paid work).

The state-related section aims at seizing the effectiveness of income transfer schemes and policy reforms to protect working families from falling into poverty. As Sen (1976) argued that a satisfactory aggregate index of poverty should capture any income transfer among the poor, he added a third component to the poverty index he proposed: income inequality among the poor (see Box 1 on the Sen's index of poverty). The analysis of public social transfers lends itself to the use of a distribution-sensitive poverty indicator. Hence the two poverty measures considered here: the Gini coefficient of the equivalised disposable income before and after public social transfers among the working poor.

as Euromod. Although it would yield more precise results, the option of resorting to Euromod is suggested for future investigation. 
Box 1. The Sen's Index of Poverty

The standard measure of poverty is the poverty rate, the proportion of people living on less than the poverty line. If the poverty line is defined as a share of the national median income, then the poverty rate is a relative measure of poverty. It is to be opposed to the absolute measure of poverty where the poverty threshold is defined as a minimum of subsistence level, say $\$ 2$ a day at year $\mathrm{n}$ international prices. It is also called the 'headcount ratio' to distinguish it from other poverty indicators such as the poverty gap. The Sen's index of poverty combines the headcount ratio with another two rates: depth and inequality:

- $H$ : the 'headcount' ratio divides $p$, the number of people with income $y_{i}$ no higher than the poverty threshold $Z$, by the total population size $n$ :

$$
H=p / n
$$

- $I$ : poverty 'intensity' or 'depth' or the 'income-gap' ratio. The income gap $g_{i}$ any individual $i$ is the difference between the poverty line $z$ and his or her income $y_{i}$, expressed as a percent share of the poverty line:

$$
g_{i}=\left(z-y_{i}\right) / z
$$

The intensity of poverty is the weighted sum of the income-gap ratios $g_{i}$ of everyone being counted as poor:

$$
I=\sum_{i=1}^{p} g_{i}
$$

- Gini is the Gini coefficient of the income distribution of the poor, ranging from 0 (perfect equality) to 1 (complete inequality). The Gini coefficient may be seen as the average (of absolute) difference of income between any two individuals randomly taken among the poor, relative to (weighted) average income of the poor Bourguignon (2012:12-13).

Sen demonstrated that for large numbers of the poor, the poverty index tends to the following limit:

$$
\text { Sen }=H[I+(1-I) \text { Gini }]
$$

Sen's index is an increasing function in $H$, I and Gini.

Why combining these three rates together? In 1976, Sen pointed that the headcount ratio as the sole poverty indicator necessarily offers an incomplete understanding of poverty and argued for a synthetic index of poverty. First, counting the number of people living under the poverty line does not say anything on how poor an individual may be: to which extent is this person's income departing from the poverty line? Providing an answer to this question, the income gap ratio makes the synthetic indicator of poverty vary in the same direction, i.e. the latter increases as a person living below the poverty line is further impoverished (monotonicity axiom). Likewise, measuring the distance between the average income of the poor and the poverty line does not capture the distribution of income among the persons living below the poverty line: how best to measure the impact of any income transfers between two persons below the poverty threshold on inequality among the poor? Sen suggested to measure inequality among the poor based on the Gini coefficient so that the synthetic index is an increasing function of the inequality indicator (transfer axiom). Overall, the Sen's index of poverty is an increasing function in its three components. 


\section{Poverty and Standard Employment}

This section lays the emphasis on the wage effect of the Great Recession on working poverty. Labour-market insiders typically work under regular employment contracts. Standard employment usually refers to an open-ended position in fulltime employment under a permanent contract as employee. Retrieving those job characteristics in EU-SILC leads to define the poverty rate as the share of people hired on a full-time basis, all year long, whose labour income falls below the poverty threshold anchored at year 2008. The results appear in Figure 4.

Figure 4. Poverty and Standard Employment

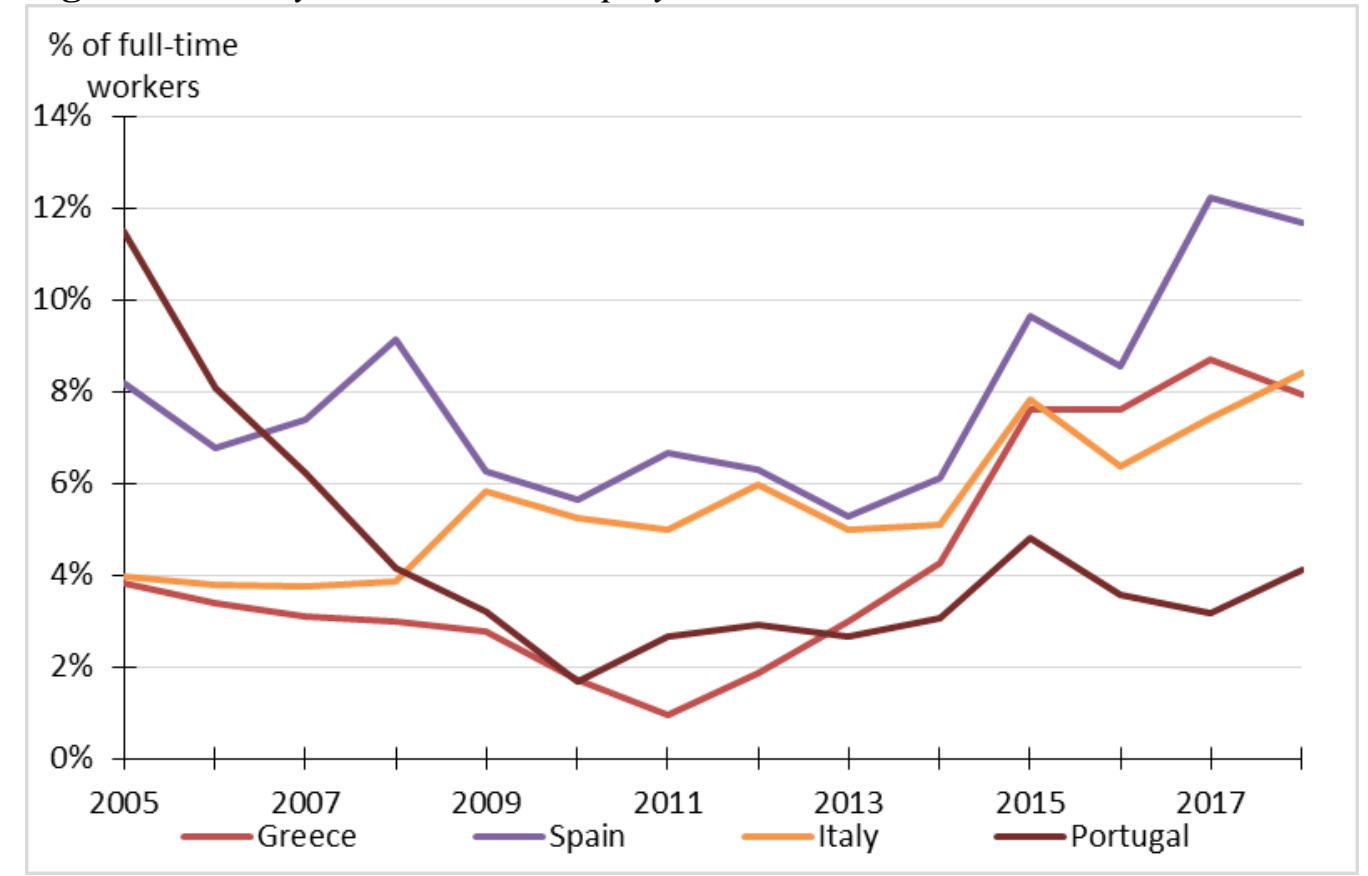

Source: Author's Own Calculations using EU-SILC Microdata.

Note: Population of the 18-64 years-old employees working on a full-time basis all year long. Poverty thresholds anchored at year 2008 and adjusted for price inflation. The measure of income is individual earned income.

The poverty trends of workers in regular employment yield worrying results despite the extremely low rates recorded prior to the double-dip recession (less than 2\% in Greece and Portugal in 2010-2011). The working poverty for the insiders has doubled in Spain, Italy, and Portugal and has been multiplied by $8 \%$ in Greece in less than a decade. Spain, Italy and Greece lie above the $8 \%$ line at the end of the period while Portugal displays a flatter slope.

Shall we conclude from these results that the Great Recession has eventually introduced a breach in the unassailable fortifications of the labour market insiders of Southern Europe? Anne Fretel (2016) analyses the concept of labour-market dualism this way: it "is read as the result of an opposition between insiders/ outsiders such as theorized by Lindbeck and Snower (1988): insiders _ supported by trade unions or labour law _ have influence over the companies' decisions to hire or set salary levels; the power of influence in turn works against outsiders 
because of the existence of turnover costs." She pinpoints the policy implications derived from that theory. The growth rate of nominal wages has long been depicted as the primary culprit for current account imbalances, counter-performing the profit rates of firms, degrading the external competitiveness of a nation in the European context of a monetary union such as the euro zone. Wage moderation has been presented as the first-choice tool to the way out of a crisis since the 1990s (even though the IMF (2015) reckons that the "more countries undertake wage moderation together, the smaller is the competitiveness effect and the larger is the demand effect and thus the smaller the benefits and the larger the costs of wage moderation for these economies"). Two decades later, the IMF (2015) notes the decline of wages relative to productivity in crisis-hit economies of the euro zone. Wage moderation is therefore the primary explanation suggested for the sharp upward trend of poverty observed for the labour-market insiders in the four countries since 2010-2011.

How deep has the poverty gap accruing to the labour-market insiders in poverty been evolving since 2005? Figure 5 offers a glimpse of the answer by showing how far the individual earned income of the poor working full-time all year departs from the national poverty thresholds between 2005 and 2018.

Figure 5. Poverty Gap of Workers in Regular Employment

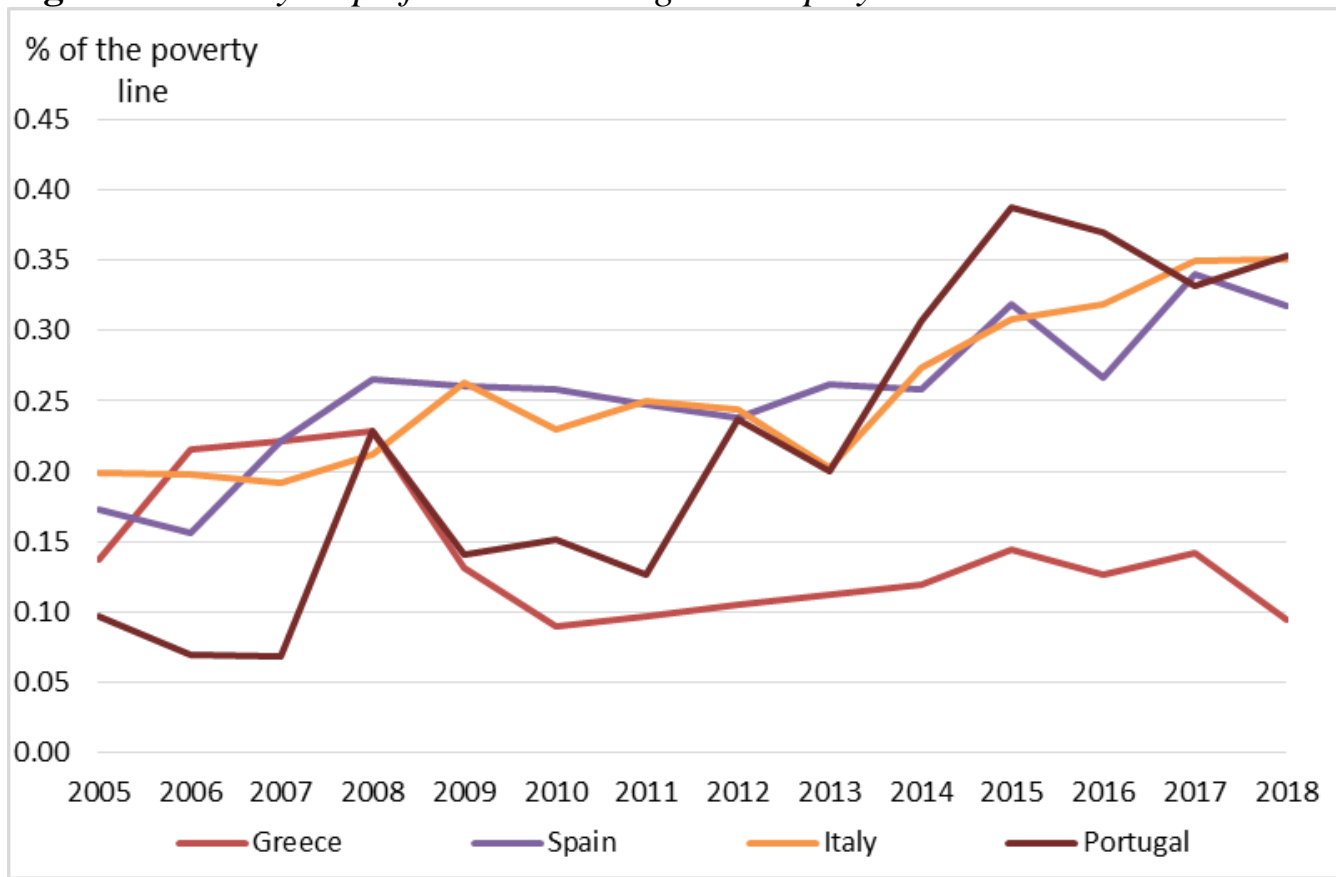

Source: Author's Own Calculations using EU-SILC Microdata.

Note: Population of the 18-64 years-old employees working on a full-time basis all year long. Poverty thresholds anchored at year 2008 and adjusted for price inflation. The measure of income is individual earned income. For cross-national comparison to be possible, we computed the relative poverty gap, which is expressed as a percentage share of the poverty line.

Whether wage earnings started to deviate away from the poverty threshold in 2010, 2012 or 2013, the wage shortfall of the poor in standard employment appears to be particularly salient in Portugal, Spain and Italy. Between the minimum and 
maximum points over the period, the percentage point difference varies from 14 points in Greece to 32 points in Portugal. By contrast, the same difference in the working-age population (rather than the population of regular workers) varies from 8 to 12 percentage points.

The next two sections deal with the employment effect of the Great Recession on working poverty. The European Commission (2018, p. 118) clearly explains the global economic forces at play over the long-run: "Permanent full-time employment may continue to decrease in the future. While the extent of the impact of technological change and new forms of work on non-standard contracts is not yet clear, permanent full-time employment has decreased by 4 pps over last 15 years (59\% in 2016)" and "the rise of new forms of employment reflects structural transformations in the world of work which have tended to lead to increasingly flexible work arrangements." The workers in non-standard employment cannot be uniformly defined. When it refers to the self-employed, those range from the medical doctor earning high salary to the freelancer working on an Uber-type of platform hardly making ends meet. It also mixes together workers of poor educational endowments, alternating spells of inactivity with spells of unemployment or precarious jobs, with highly qualified workers, conceding to contract mini-job positions because of a job-skill mismatch that has continued for too long a period of time. In Portugal, the diversification of atypical employment has taken the form of "green receipts" (recibos verdes) on the rise since the late 1990s. It consists in a batch of vouchers at the disposal of the independent worker to invoice the company for services mostly delivered on site. Such a system thereby discharges the employer from all liability in terms of basic labour laws (paid leave, sickness or unemployment benefits, and so on). Affecting all skill levels, such a practice has spread to the point of becoming a common form of employment as early as 2009 with over 900,000 Portuguese workers being affected (Pernot, 2009). In Italy, the "para-subordinate" workers (lavoratori parasubordinati), a subcategory of self-employed workers, "are not covered by the vast bulk of employment regulations, including individual and collective dismissal legislation, maximum working hours and paid holidays regulations" (ILO, 2016). In Greece, the rise of on-call work has nurtured atypical employment. On-call work refers to casual work of an intermittent nature. Variable and unpredictable, the hours worked on-call work are generally part time (ILO, 2016). In Spain, temporary employment records the highest rates in Europe and in the world. The share of Spanish workers with fixed-term contracts in all employees remains above that of the three other countries, although the double crisis has curbed its slope below the $25 \%$ threshold since 2009 (ILO, 2016).

Usually granting only very limited social rights to their holders, these new forms of employment contracts tend to fuel the risk of poverty (COE 2015, p. 26). In this context, to which extent is the rise of non-regular employment an explanatory factor of working poverty over the past decade? To answer this question, two population subgroups highly exposed to the poverty risk are distinguished: the self-employed hiring no staff, and the part-timers who are willing and available to work more hours but who cannot for economic reasons. 


\section{Poverty and Self-Employment}

Eurostat data online show that in 2018, the share of the self-employed was highest in Greece and Italy. "Across the EU Member States, almost one in every three people in employment in Greece was self-employed in 2018 (30\%) and around one in five in Italy $(22 \%)$ ".

Numerous studies link poverty and self-employment but few do so on long periods of time. McKnight et al. (2016, p. 57) summarize the situation this way: "People who are self-employed also tend to have a higher poverty risk than those working for an employer (Ray et al., 2014). Using 2007 EU-SILC data across the EU, Eurofound (2010, cited in Ray et al., 2014) find the risk of poverty among self-employed people to be three times higher than among the employed: 18 per cent compared to 6 per cent. Ponthieux (2010) adds that living with others who work lowers the poverty risk, except when both the worker him/herself and the other workers in the household are self-employed."

According to Eurostat, the poverty risk of the self-employed in the four Southern European countries ranges between 15\% and 35\% between 2005 and 2018. These measures necessarily record low ranges of poverty compared to the poverty rates based on individual labour income, a poverty line anchored in time, and an extended definition of workers (Figure 6).

Figure 6. Poverty Rates of the Solo Self-employed, 2005-2018

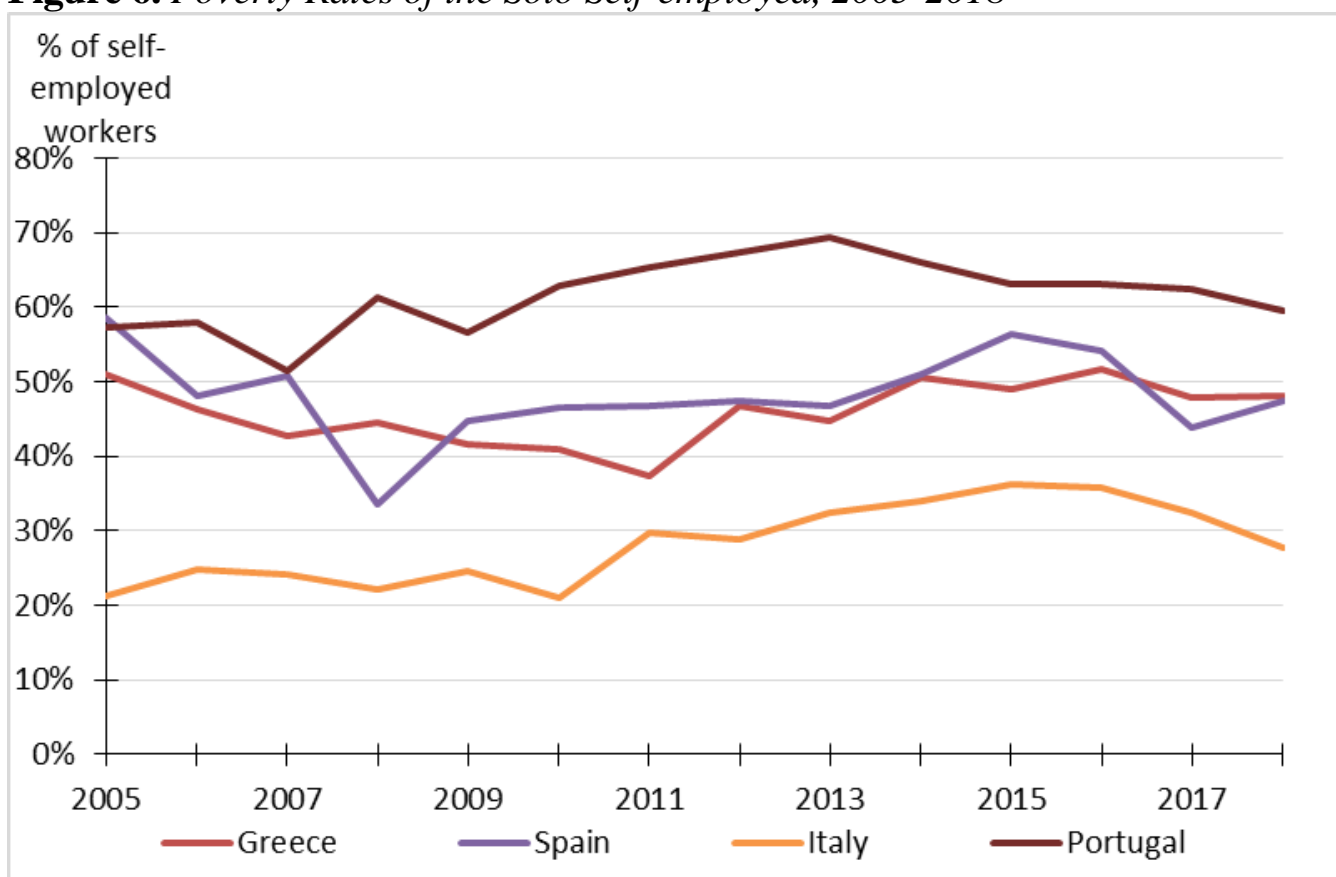

Source: Author's Own Calculations using EU-SILC Microdata.

Note: Population of the 18-64 years-old self-employed workers hiring no staff. Poverty thresholds anchored at year 2008 and adjusted for price inflation. The measure of income is individual earned income. 


\section{Poverty and Involuntary Part-Time Employment}

In the four countries of Southern Europe, involuntary part-time work in overall part-time employment lie well above the European average during the last decade. Its prevalence has spread with the onset of the double-crisis of 2008-2010 as shown in Figure 7.

Figure 7. Involuntary Part-Time Employment, 2005-2018

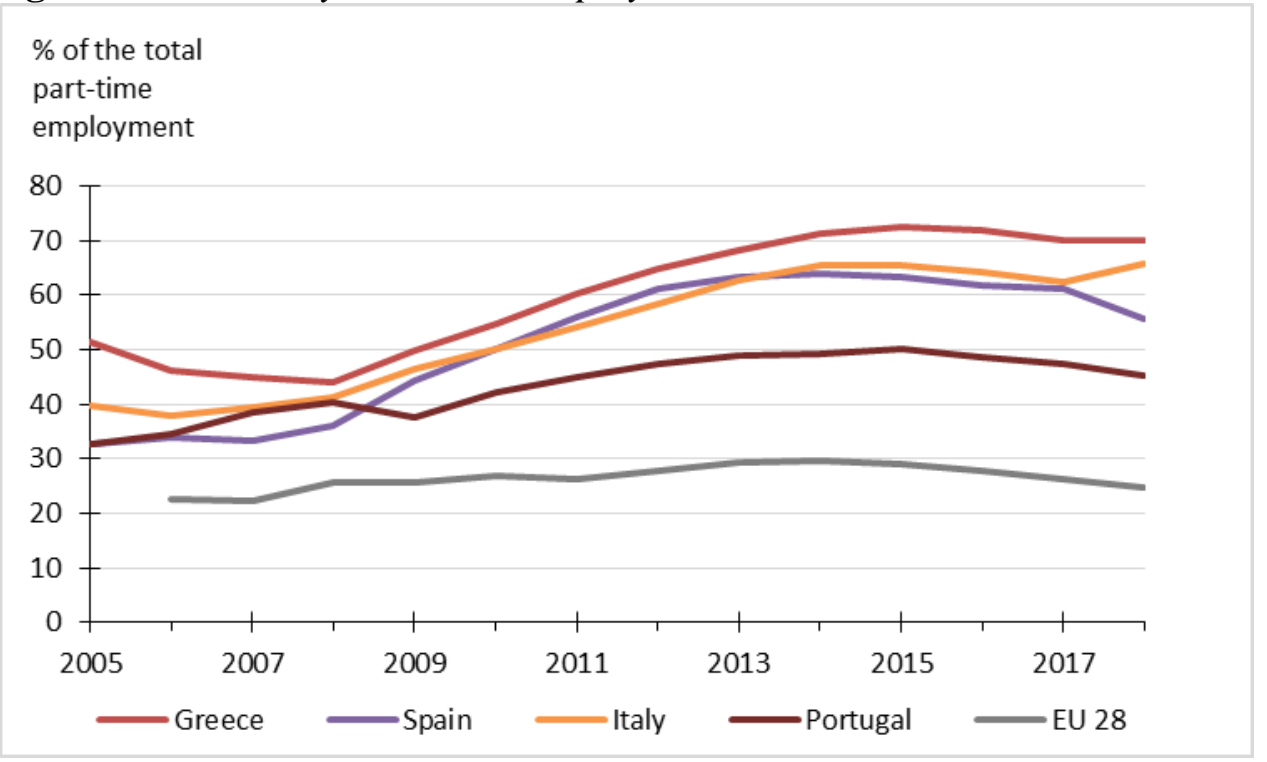

Source: Eurostat. LFS series - detailed annual survey results (lfsa_eppgai).

At the EU-level, Heyes and Lewis (2014, quoted in McKnight et al., 2016) associate the increase in involuntary part-time and temporary employment since the start of the crisis in 2007 to the rise in the incidence of in-work poverty across EU member states. Considering employees with a temporary contract, Eurostat records in-work national poverty rates varying within the 5\%-25\% interval between 2005 and 2018 in the four countries considered. Figure 8 provides a different picture with poverty rates ranging between $40 \%$ and $80 \%$ over the same timeperiod in the same places. It represents the share of adult persons constrained in part-time employment who would be poor (given a poverty threshold anchored in time) had they lived on their own and from their earned income only.

In Greece, one possible explanation is provided by Karakioulafis (2017). The author mentions the difficulties that an increasing number of employers face when it comes to paying the wages of their employees on time. The worker's compensation is sometimes postponed for several months in a row or being replaced by small sums of money instead. "This is one of the statistically unmeasurable and less visible faces of the casualization of working conditions" (p. 4).

These results amplify the European Commission's conclusions. At the EU-28 level from 2008 to 2016, the "rise of in-work poverty among non-standard workers underlines the challenge of ensuring that flexible labour market arrangements do not disproportionately affect the most vulnerable workers. This in turn emphasizes the need to address in-work poverty" (European Commission, 2018). The same 
institution further investigates the question: "Alongside minimum wages, policy that tackles low pay more broadly, promotes continued wage and career progression, and reduces temporary contracts and involuntary part-time work is also vital. Poverty risk is especially high for workers who are part-time but looking for a full-time job, making the availability of longer hours a priority area for policy action. There is evidence that the weakening of unions in many European countries in recent decades has been damaging to the situation of lower paid workers. Governments should consider how to redress this balance" (McKnight et al., 2016, p. 112).

Figure 8. Poverty Rates for Workers in Involuntary Part-Time Employment

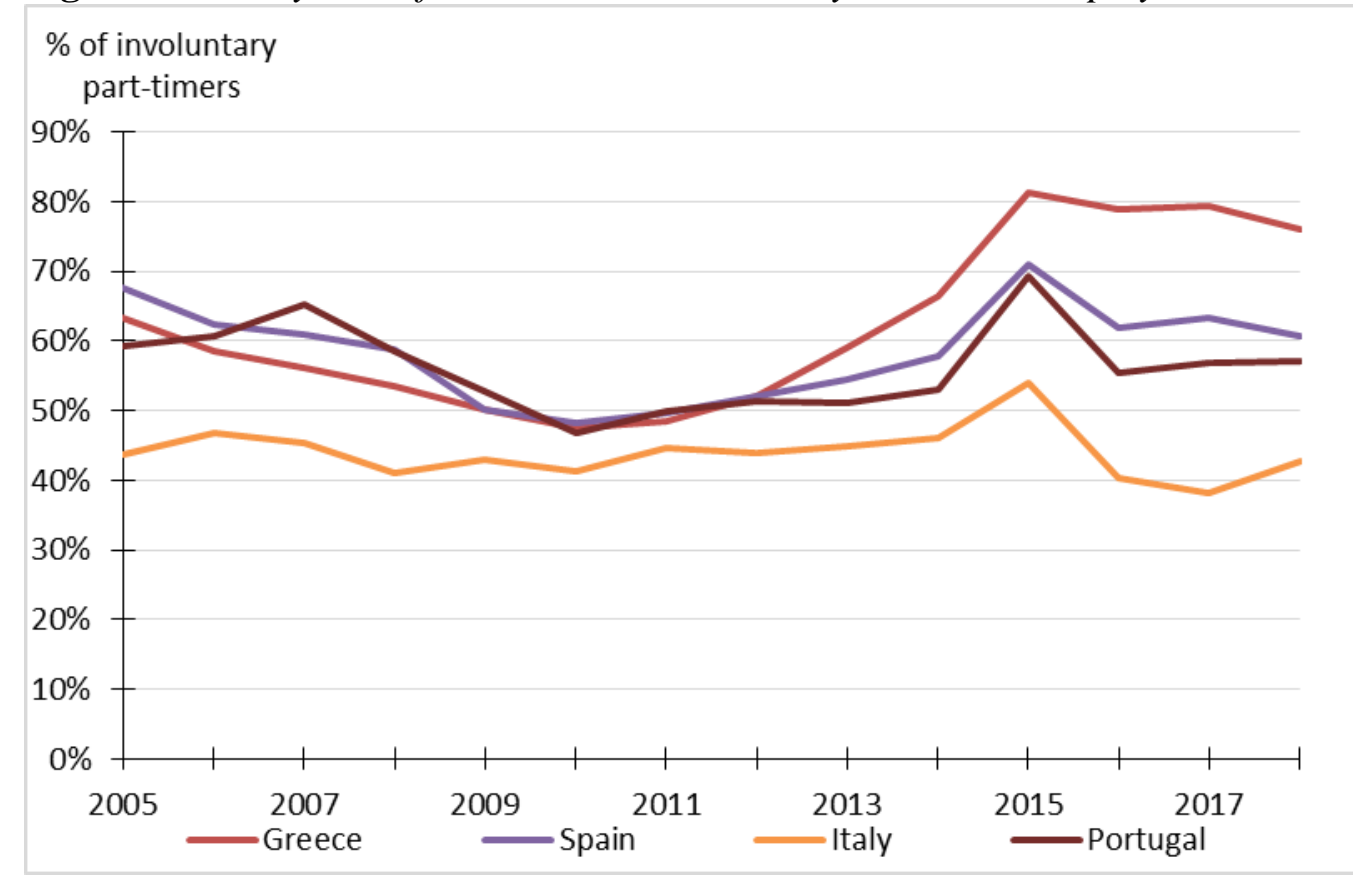

Source: Author's Own Calculations using EU-SILC Microdata.

Note: Population of the 18-64 years-old individuals constrained to part-time work. Poverty thresholds anchored at year 2008 and adjusted for price inflation. The measure of income is individual earned income.

\section{Poverty and Working Families}

The classical argument opposed to an individual approach of poverty is that most people being poor in the individual measure of income do live in non-poor families, thereby being rescued by the family net. How many workers being poor in labour income do live in a non-poor household in the main four countries of Southern Europe between 2005 and 2018? The results appear in Figure 9. 
Figure 9. Share of Poor in Personal Labour-income living in Non-poor Households, 2005-2018

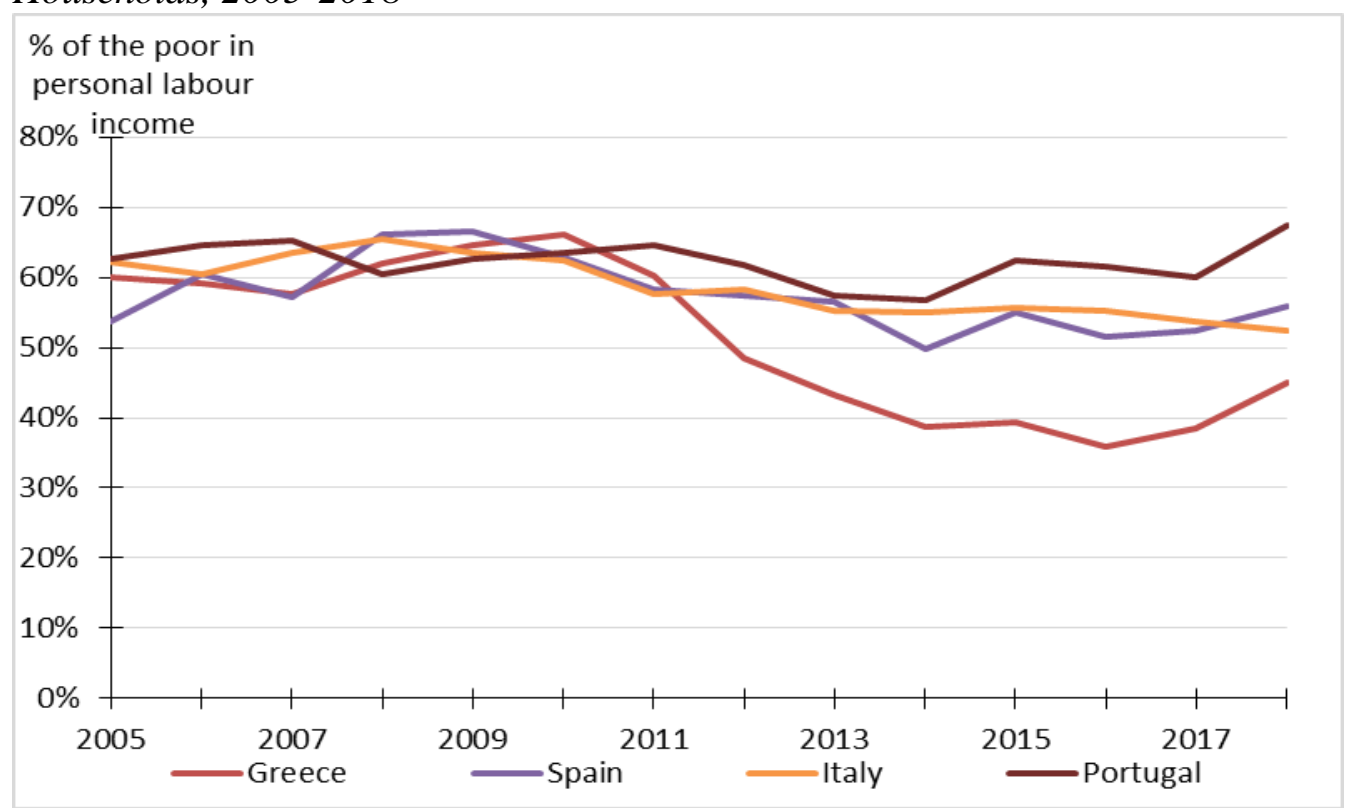

Source: Author's Own Calculations using EU-SILC Microdata.

Note: Population of the 18-64 years-old persons spending at least one month a year at work. Poverty thresholds anchored at year 2008 and adjusted for price inflation. At the numerator, the measure of income is individual earned income expressed in current prices. At the denominator, all equivalised disposable incomes above the poverty line are considered.

The series plotted on the graph above mark a break with pre-crisis levels. First stagnating, the proportion of working adults who would fall into poverty without their family protection has been declining clearly since 2010. Put under economic pressure, the family net in Greece has rescued less than half of the working poor since 2012.

Going one step forward on this issue adds a gender component to the economic profile of the poor. Because women are over-represented in both lowpaid jobs and part-time work, they "are more reliant than men on a partner's wages to lift them out of poverty, which also makes them more vulnerable to poverty resulting from family break-up" (Ray et al., 2014). Among the working-age adults being poor in labour income and living in a non-poor household, about $70 \%$ of them were female adults in all of the four countries in 2005. However, that share has steadily decreased along a quasi-linear path since then, to finally set around $60 \%$ in all four countries from 2015 on. Despite the persistent gender divide in society, the family dimension (from its protective side) has given ground to the labour market dimension of poverty with the occurrence of the Great Recession.

\section{Poverty and State}

The intent of this section draws inspiration from the works by Petmesidou \& Papatheodorou (2006) about the effectiveness of income transfer schemes and about the policy measures typical of the 1990s and 2000s in Southern Europe. 
Petmesidou and Papatheodorou first sketch the institutional landscape of that time: "Overall cash transfers exhibit a strong 'pension bias' (a characteristic Greece shares with Italy). The few non-contributory (some of them means-tested) categorical benefits are characterized by great gaps in coverage and high fragmentation. Equally fragmented and polarized are social insurance benefits" (p. 54). The authors then compare two years, 1994 and 2001 using a series of inequality indices based on total disposable equivalent household income: the Gini index, two variants of the Atkinson index, the Theil's Entropy Index, the mean logarithmic deviation, and another measure derived from the coefficient of variation. All of their estimates show a decline in economic inequality in the four countries between 1994 and 2001. The authors attribute this result to the introduction of progressive policy measures of the late 1990s. Indeed, the guaranteed minimum income scheme was introduced in Portugal in 1996 and implemented to the whole country a year later under the name of 'minimum insertion income' (Reddito Minimo di Inserimento); Spain expanded regional minimum income programmes in the meantime; and Italy initiated the social allowance, the benefit to large families or the national fund supporting low-income tenants (p. 57).

How effective have the public social transfers been to reduce economic inequality since then? One way to address the question is the computation of one inequality indicator, the Gini coefficient, measured twice, before and after public social transfers, plotted over time (Figure 10).

Figure 10. Gini Coefficients of EDI before \& after Social Transfers, 2005-2018 Panel A) Greece and Spain

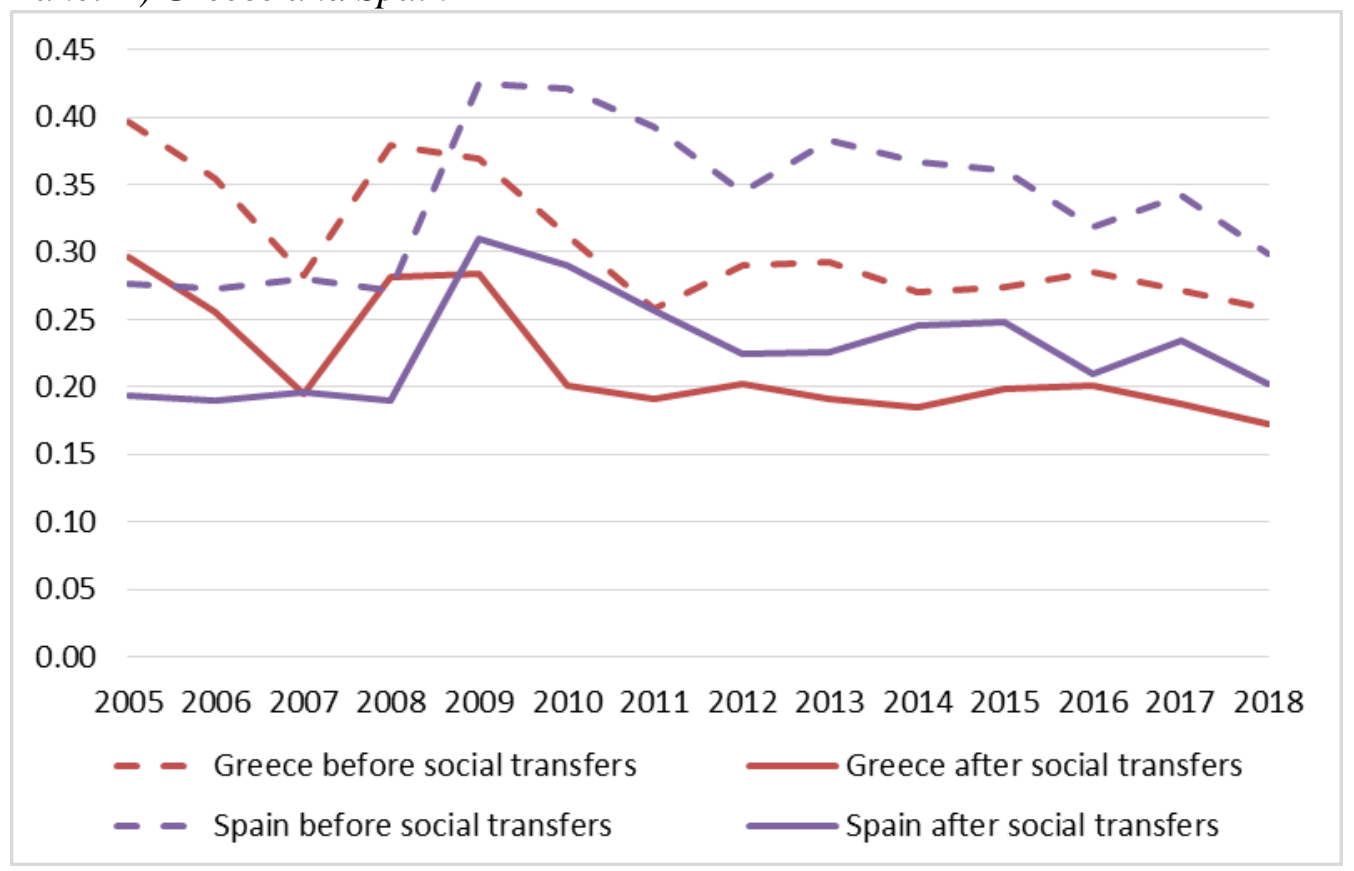


Panel B) Italy and Portugal

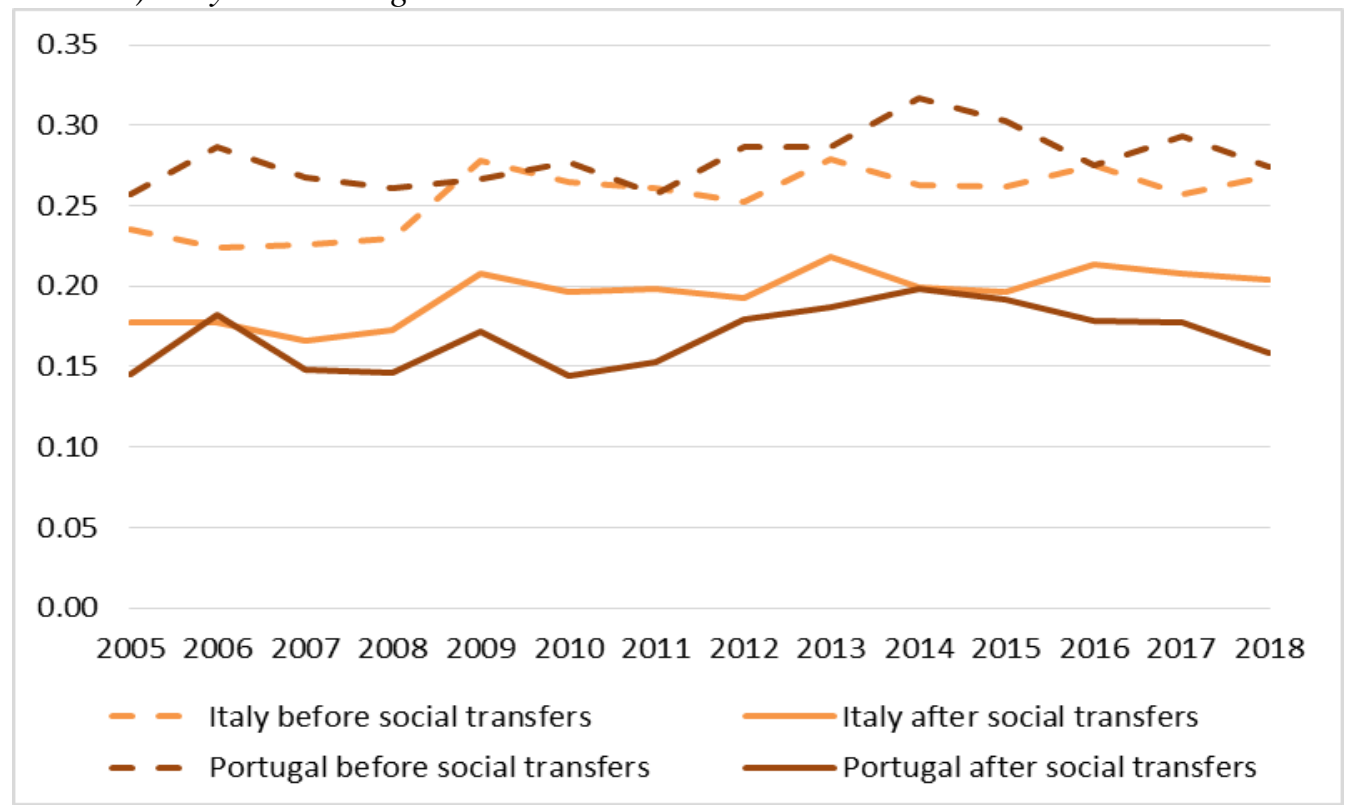

Source: Author's Own Calculations using EU-SILC Microdata.

Note: Gini index among the working poor. Population of the 18-64 years-old persons spending at least one month a year at work. Poverty thresholds anchored at year 2008 and adjusted for price inflation. The measure of income is equivalised disposable income (EDI) before and after social transfers, both expressed in current prices.

Before interpreting the results of these two graphs, let us keep in mind that the comparison with Petmesidou's and Papatheodorou's estimates is a tricky exercise. Unless otherwise stated, Petmesidou \& Papatheodorou apply the inequality indices to the whole national population, whereas the two Gini coefficients presented in Figure 10 are restricted to the working poor population.

The inequality decline recorded between 1994 and 2001 in all four countries contrasts with the bumpy curves of the Gini coefficients in Greece and Spain (Panel A). The turning points of 2007-2008 and 2011-2012 make the association between the Great Recession and inequality among the working poor appear quite clearly in these two countries. In Italy overall and in Portugal up to 2014, income inequality among the poor, whether measured before or after social transfers, displays an upward trend (Panel B).

The occurrence of the Great Recession has totally changed the pace and the nature of the public policies implemented in Southern Europe, giving rise to fundamental labour market reforms. Figure 11 illustrates this point. 
Figure 11. Labour-Market Reforms before and after 2008

Panel A) 2000-2007

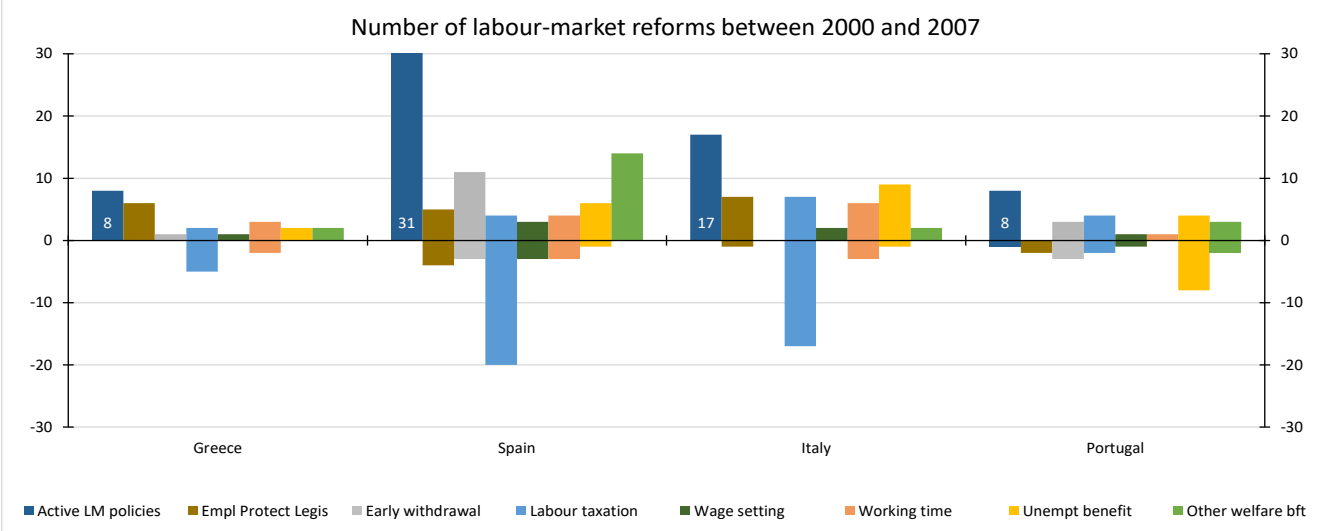

Panel B) 2008-2017

Number of labour-market reforms between 2008 and 2017

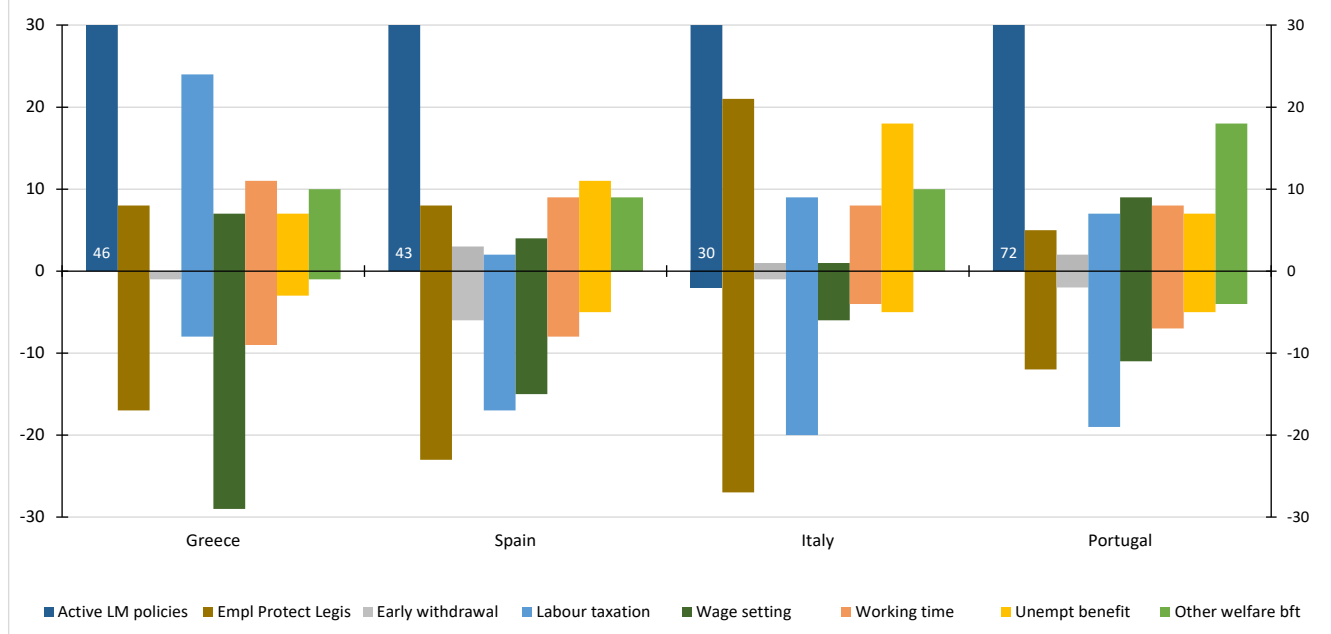

Source: Labour Market Reforms Database by the European Commission (LABREF).

The labour market reforms database (LABREF) published by the European Commission (2017) tracks the number of labour-market reforms that European Union member states have implemented since 2000. Each policy measure associates a positive or negative sign with its initial goal. A positive sign means:

- in the wage setting legislation, any agreement tightening framework conditions for wage setting on the part of employers;

- in the employment protection legislation, measures increasing protection against job dismissals, restricting the conditions for the use of temporary contracts and temporary agency work, but also, measures increasing rights and working conditions of workers;

- in the welfare benefit legislation, any measure increasing the generosity of benefits or easing entitlement conditions: unemployment benefits, shorttime working schemes; in-work benefits, i.e. employment conditional benefit or tax credit (workfare); social assistance (housing, means-tested benefits); sickness schemes excluding disability; family-related benefits. 
Conversely, a negative sign reports "decreasing" policy measures.

All four countries actively carried out a series of reforms, "packages" of temporary and permanent measures, disentangling almost all aspects of the employment protection legislation. They devaluated collectively bargained wages from the industry-level to the firm-level in Portugal in 2009 and 2014, Spain in 2010 and 2012, Italy in 2009 and 2011. Setting wage moderation as a priority, Portugal froze the minimum wage for four years in a row (from 2011 to 2014). The social-sciences literature abounds in other examples of decreasing labourmarket reforms: Vincent $(2012,2016)$ for Spain, Rehfeldt (2016) for the Italian case, Pernot and Rego (2014), and Rego and Pernot (2017) for Portugal, and Karakioulafis (2017) for the Hellenic republic, Chagny \& Husson (2015) at the European level and Fretel (2016) for OECD countries.According to the COE (2015 a, p. 101), no strong ties can be observed between poverty trends and the labour-market reforms carried out in all Europe Union member states in the new millennium. "In the countries that only started their reforms with the crisis (Spain, Ireland, Italy, Portugal), the increase in poverty seems to be mainly due to the functioning of the labour market (employment effect and wage effect)"'. Does the working poverty observed in Southern Europe in recent years take roots solely in the national labour-market structures? There are reasons to cast doubts on it. One is the state of emergency in which these policies were integrated in the national legislation. Adopted in a hurry, out of the trade-union circles, the decreasing labour-market reforms were conducted under very strong external pressures, first as a counterpart to the financial assistance provided by the European institutions and the International Monetary Fund; and second as payback for taming interest rates at sustainable levels on the financial markets, in the specific context of fiscal consolidation. Fiscal consolidation usually consists of a recessive combination of lay-offs in the public sector, and cuts in social spending one the one hand, to broader tax bases and various other tax revenue measures on the other hand. Embedding negative spillovers on economic growth, fiscal consolidation depresses employment, thereby threatening households' disposable income. Overall, the poor and the vulnerable persons of society can hardly bear the brunt of it (Darvas \& Tschekassin, 2015). .

In terms of poverty, Eurofound (2017) links the fiscal consolidation policies, including labour taxation, to labour poverty (Box 2). So do Pernot and Rego (2014): "Deep budget cuts in public finances, large-scale privatization programs and deregulation of the labour market have been faithfully implemented by the Portuguese government. The overall effect of this policy on society has a heavy toll: poverty has spread, the resolution of the country's structural problems (health, education in particular) has declined. Income inequalities, traditionally high in Portugal, have been on the rise since 2010 after ten years of continuous reduction".

Finally, if the labour-market reforms making the working poor of Southern Europe worse off since 2010 is always an arguable hypothesis, what is less disputable is the people's perception of the crisis. Darvas \& Tschekassin (2015) sum it up precisely: "According to Eurobarometer (2012), which is the sixth and most recent wave of monitoring of public perceptions on the social impact of the crisis, 80 percent of respondents think that poverty has increased in their country 
over the past 12 months, while 67 percent say it has increased in the EU. The survey also suggests a growing sense of hopelessness and insecurity in a number of EU countries."

\section{Box 2. The Effect of the Economic Crisis on Income in Greece}

Since 2009, Greece has seen a drastic reduction in minimum wages and incomes as a whole. At the same time, taxes increased for both employees and the self-employed, and social security contributions for the self-employed increased. Furthermore, a series of measures have been introduced to facilitate labour flexibility. All this has resulted in reduced incomes and spending power for workers, as well as a fall in both the average disposable income and the poverty line. Specifically, minimum wages in Greece have fallen as a result of legislation in 2012 (Law 4046) by $22 \%$ (from $€ 751$ per month to $€ 586$ per month) and by $32 \%$ for young people under 25 (to $€ 510$ per month).

The rise in flexible forms of employment (with the main effect being the conversion of full-time employment to part-time employment or job rotation) has significantly reduced income from salaries. The General Confederation of Greek Workers (GSEE) estimates that 500,000 part-time employees are paid net salaries less than the minimum unemployment benefit, which comes to $€ 360$ per month.

In terms of the taxation of employees and the self-employed, under a series of laws enacted since 2010, the tax-free threshold has been reduced, tax breaks have been abolished, indirect taxation (VAT) has been increased, and taxation of housing has been increased, all having the effect of drastically reducing income from work. For example, Law 4387/2016 reduced employees' tax-free threshold of $€ 9,545$ to $€ 8,636$. Other categories of workers (freelancers and business owners) are taxed on every euro earned. Moreover, the average social security contributions for the self-employed and freelancers increased by $20 \%$.

Source: Eurofound (2017, p. 35).

\section{Conclusion}

Italy, Spain, Portugal and Greece all have experienced years of economic recession, political and social turmoil in the aftermath of the sovereign debt crisis. The standard measures of poverty risk fail to capture the Great Recession over this time period in that part of the world. Three technical adjustments need to be performed to make the double crisis of 2008-2010 appear clearly: a poverty line kept stable over time, a broader definition of workers, and an individual approach to poverty. EU-SILC microdata 2005-2018 reveal that wage moderation over the past decade has acted as the primary factor of working poverty among the employees working on a full-time basis all year long, had a worker lived from labour resources only. Besides, the wage shortfall of the poor in standard employment has sharpened since the early 2010s particularly in Portugal, Spain and Italy.

The data also showed that the rise of non-regular employment boosted working poverty, from the turning point of 2010 to 2015, of two population subgroups, the self-employed adults hiring no staff, and the individuals constrained to work part-time, in much wider proportions than the standard measures usually suggest. 
The share of workers being poor in individual earned income but who live in a non-poor family has decreased as the result of the economic crisis, to worrisome levels in the Hellenic republic. Bending under strong economic stress, the family net does not play as effectively as it did in the past.

Finally, the double crisis of 2008-2010 has fundamentally changed the state dimension of working poverty. Usually, the redistributive effect of the state is mainly accounted for by public social transfers. However, the welfare-related benefits, though still a key determinant for lifting people out of poverty, are no longer the primary variable featuring the state institution. "Decreasing" labourmarket reforms are. The latter ones have a recessive impact on wage levels and employment duration, hurting the poor first. Combined with austerity measures as regards social transfers, they contributed to fuel income inequality among the working poor around the two turning points of 2007-2008 and 2011-2012 in Greece and Spain, up to 2014 in Portugal and over the entire time period in Italy.

\section{References}

Allègre G. 2012. "Work, Family or State? From wage inequalities to standard of living inequalities and in-work poverty in a European cross-country perspective". OFCE. Document de travail 2012-12. April.

Central Statistics Office (CSO) of Ireland. 2018. Standard Report on Methods and Quality for the 2017 Survey on Income and Living conditions (EU-SILC). Quality Report.

Chagny O., Husson M. 2015. Looking for an "optimal wage regime" for the Euro zone. IRES Working paper $\mathrm{N}^{\circ} 01$. January.

Concialdi P. 2014. «Les budgets de référence: un nouveau repère dans le débat public sur la pauvreté». La Revue de l'IRES. № 82. 2014/3.

Conseil d'orientation pour l'emploi (COE). 2015a. «Les réformes des marchés du travail en Europe. Tome 1. Rapport général». 5 November.

Conseil d'orientation pour l'emploi (COE). 2015b. «Les réformes des marchés du travail en Europe. Tome 2. Monographies: Allemagne, Autriche, Danemark, Espagne, Irlande, Italie, Pays-Bas, Portugal, Royaume-Uni, Suède». 5 November.

Crédoc, IRES. 2014. ONPES reference budgets. Final report. July.

Crettaz E. 2015. "Poverty and material deprivation among European workers in times of crisis". International Journal of Social Welfare. Vol. 24, pp. 312-323.

Darvas Z.M., Tschekassin O. 2015. "Poor and under pressure: The social impact of Europe’s fiscal consolidation”. Bruegel Policy Contribution. №2015/04. Bruegel. Brussels.

Dicharry B., Terra I. 2016. «Les conséquences de l'austérité sur le niveau de vie des chômeurs dans le sud de l'Europe». Bulletin de l'Observatoire des politiques économiques en Europe. Université de Strasbourg: Bureau d'économie théorique et appliquée (BETA). $\mathrm{N}^{\circ} 34$, p. 27-32.

Eurofound. 2017. In-work poverty in the EU. Publications Office of the European Union. Luxembourg.

Eurofound. 2010. Working poor in Europe.

European Commission. 2017. "Coverage and structure of the Labour Market Reform (LABREF) Database". November. http://ec.europa.eu/social/main.jsp?catId=1143\& intPageId=3193\&langId=en 
European Commission. 2018. Employment and Social Developments in Europe. Annual Review 2018. European Union. doi:10.2767/875456

European Union Statistics on Income and Living Conditions (EU-SILC), cross-sectional data, user database 2005-2018, version of 2019-09.

European Union Statistics on Income and Living Conditions (EU-SILC), cross-sectional data, user database 2004-2017, version of 2019-03.

Fretel A. 2016. "Réformes du marché du travail: que disent les «exemples» étrangers?», Chronique Internationale de l'IRES, ${ }^{\circ} 155,2016 / 3$, p. 3-25.

Horemans J., Marx I., Nolan B. 2016. "Hanging in, but only just: part-time employment and in-work poverty throughout the crisis". IZA Journal of European Labor Studies. 5:5.

Horemans J., Marx I. 2017. "Poverty and Material Deprivation among the Self-Employed in Europe: An Exploration of a Relatively Uncharted Landscape", IZA DP No. 11007.

International Labour Office. 2016. Non-standard employment around the world: Understanding challenges, shaping prospects. Geneva.

International Monetary Fund. 2015. "Wage Moderation in Crises: Policy Considerations and Applications to the Euro Area”. Prepared by Decressin J., Espinoza R., Halikias I., Leigh D., Loungani P., Medas P., Mursula S., Schindler M., Spilimbergo A., Teng Teng Xu. IMF Staff Discussion Note 15/22. November.

Jenkins S. P., Brandolini A., Micklewright J., Nolan B. 2013. The Great Recession and the Distribution of Household Income. Oxford University Press.

Karakioulafis C. 2017. «Grèce. Nouveau bras de fer avec les créanciers internationaux: quels enjeux sociaux?» La Chronique internationale de l'IRES. $\mathrm{N}^{\circ} 159$. September.

Marx I., Nolan B. 2012. In-Work Poverty. AIAS, GINI Discussion Paper 51.

McKnight A., Stewart K., Himmelweit S.M., Palillo M. 2016. "Low pay and in-work poverty: preventative measures and preventative approaches". Evidence Review. European Commission. Luxembourg: Publications Office of the European Union.

Meulders D., O’Dorchai S. 2010. "Revisiting Poverty Measures Towards Individualisation”, DULBEA, Université Libre de Bruxelles, Working paper 10-03 Research Series.

Mussard S., Pi Alperin M. N. 2011. "Poverty growth in Scandinavian countries: A Sen multi-decomposition". Economic Modelling. 28(2011) 2842-2853.

Observatoire national de la pauvreté et de l'exclusion sociale (ONPES). "Reference budgets: Assessing the needs to be met for an effective participation in society". 2014-2015 Report.

Orshansky M. 1965. "Counting the Poor: Another Look at the Poverty profile". Social Security Bulletin. January.

Pernot J-M. 2009. «Portugal. Une improbable gestion concertée dans la crise ». Chronique internationale de l'IRES. $\mathrm{n}^{\circ} 121$. November.

Pernot J.-M., Rego R. 2014. «Portugal. Santé, éducation, dans la tempête». La Chronique internationale de l'IRES. $\mathrm{N}^{\circ} 148$. December.

Petmesidou M., Papatheodorou C., editors. 2006. Poverty and social deprivation in the Mediterranean. Trends, policies and welfare prospects in the new millennium. CROP International Studies in Poverty Research.

Ponthieux S. 2010. In work poverty in EU. Eurostat's Methodologies and Working Papers, KS-RA-10-015-EN-N.

Ray K., Sissons P., Jones K., Vegeris S. 2014. Employment, Pay and Poverty: Evidence and policy review. Joseph Rowntree Foundation.

Rego R., Pernot J.-M. 2017. «Portugal. Un virage à gauche inédit». La Chronique internationale de l'IRES. $\mathrm{N}^{\circ} 158$. June. 
Rehfeldt U. 2016. «Italie. Le "Jobs Act", un nouveau pas vers la flexibilité pour les travailleurs et vers la sécurité pour les employeurs». La Chronique internationale de l'IRES. $\mathrm{N}^{\circ} 155$. September.

Sen A. 1976. "Poverty: An ordinal approach to measurement". Econometrica. vol. 44. nº 2.

Vincent C. 2012. «Espagne. Une réforme de plus pour flexibiliser le marché du travail espagnol». La Chronique internationale de l'IRES. $\mathrm{N}^{\circ}$ 135. March.

Vincent C. 2016. «Espagne. Dans la crise, des réformes du marché du travail radicales, mais au bilan incertain». La Chronique internationale de l'IRES. $\mathrm{N}^{\circ} 155$. September. 
